\title{
A modified method for molecular identification of Baylisascaris transfuga in European brown bears (Ursus arctos)
}

\author{
Jakub Gawor $^{1}$ (D) Jan Gawor ${ }^{2} \cdot$ Robert Gromadka $^{2}$ - Tomasz Zwijacz-Kozica ${ }^{3}$. \\ Filip Zięba ${ }^{3}$
}

Received: 12 June 2017 / Accepted: 18 October 2017 /Published online: 27 October 2017

(C) The Author(s) 2017. This article is an open access publication

\begin{abstract}
Baylisascaris transfuga is a roundworm that has been reported worldwide in most bear species. In mammals and possibly humans, the larvae of $B$. transfuga can migrate in the tissues of aberrant hosts with larva migrans syndrome. The current study was performed to identify B. transfuga in faecal samples from free-ranging brown bears in the Tatra Mountains National Park in southern Poland. A commercial kit was used to extract genomic DNA directly from faecal samples. Additionally, a Chelex resin-based technique was successfully implemented to prepare a PCR template from eggs retrieved by flotation. Based on the flotation results of 32 collected faecal samples, the prevalence of $B$. transfuga was $15.6 \%$. The parasite was confirmed in samples found to be positive during the initial flotation by a molecular assay using DNA isolated directly from faeces. The retrieved eggs were confirmed as $B$. transfuga after their DNA was extracted using the Chelex protocol. Based on PCR amplification and sequencing of a 413-bp segment of cytochrome c oxidase 1 (COI), the obtained sequence was $100 \%$ identical to the COI segment of $B$. transfuga after a BLAST comparison to the GenBank $^{\mathrm{TM}}$ database. The current study includes the first
\end{abstract}

Electronic supplementary material The online version of this article (https://doi.org/10.1007/s00436-017-5660-2) contains supplementary material, which is available to authorized users.

Jakub Gawor

gaworj@twarda.pan.pl

1 Witold Stefański Institute of Parasitology, Polish Academy of Sciences, Twarda 51/55, 00-818 Warsaw, Poland

2 Laboratory of DNA Sequencing and Oligonucleotide Synthesis, Institute of Biochemistry and Biophysics, Polish Academy of Sciences, Pawińskiego 5a, 02-106 Warsaw, Poland

3 Tatra National Park, Chałubińskiego 42a, 34-500 Zakopane, Poland molecular confirmation of $B$. transfuga in brown bears in the western part of the Carpathians. We show that direct extraction of parasite DNA from bear faeces is efficient for molecular assays. As an alternative, we present the effectiveness of a Chelex-based technique for fast and convenient DNA isolation from the difficult-to-disrupt eggs of $B$. transfuga for PCR. Molecular tests of parasite DNA extracted directly from faecal material have limits of detection related to the amount of eggs in the samples. Thus, using classical flotation to obtain eggs for PCR may increase the credibility of the results, particularly in cases with a low number of excreted eggs. The Chelex resin protocol has potential for application in studies of intestinal parasites in wildlife for which conventional flotation is routinely used for microscopy.

Keywords Baylisascaris transfuga · Brown bear · PCR . Chelex resin

\section{Introduction}

Baylisascaris transfuga is an ascarid nematode species that exclusively infects bears (Bauer 2013). It has been reported worldwide in all extant species of bears in the family Ursidae, excluding the spectacled bear (Sapp et al. 2017). B. transfuga occurs in both free-ranging and captive bears, such as the polar bear (Schaul 2006; Testini et al. 2011), American black bear (Duffy et al. 1994; Schaul 2006; Foster et al. 2004; Catalano et al. 2015), grizzly bear (Catalano et al. 2015), sloth bear (Moudgil et al. 2014) and European brown bear (Finnegan 2009; De Ambrogi et al. 2011; Szczepaniak et al. 2012; Bauer 2013; Aghazadeh et al. 2015; Bugmyrin et al. 2017).

Although $B$. transfuga is highly prevalent, as $50-100 \%$ of bears have been shown to be infected (Sprent 1968; Catalano 
et al. 2015), the pathogenicity of intestinal infection appears to be low (Bauer 2013). Nevertheless, for bears kept in captivity, baylisascariasis is a health threat due to contamination of the enclosure environment with infective stages of the parasite. An abundance of hundreds of adult specimens of B. transfuga has been reported in two polar bears in a zoo park in Italy (Testini et al. 2011). In the wild, heavy infestations could cause serious illness or death in cubs, as was shown in a young, male European brown bear with extensive abdominal lesions (granulomatous peritonitis) caused by B. transfuga (Szczepaniak et al. 2012).

The life cycle of B. transfuga is unclear (Bauer 2013), but it may be similar to that of the closely related parasite $B$. procyonis, the raccoon roundworm, a well-known cause of severe to fatal neurological disease in humans and many wildlife species (Sapp et al. 2017). Bears may become infected by ingesting embryonated eggs that are present in the environment. However, it is not known whether under natural conditions the intermediate hosts, which are prey animals, are a source of B. transfuga infection for bears (Bauer 2013). As shown in experimental infections, $B$. transfuga larvae are able to migrate in tissues of rodents, i.e. mice and Mongolian gerbils. The larvae migrate through different tissues, grow, and develop to the third stage, causing various degrees of visceral, neural or ocular larva migrans (Papini and Casarosa 1994; Papini et al. 1996; Sato et al. 2005; Cho et al. 2007; Bauer 2013).

To date, there is no unequivocal evidence of naturally occurring $B$. transfuga infection in non-ursid animals or humans (Bauer 2013; Sapp et al. 2017). The only reported case was an outbreak of fatal neurological larva migrans in Japanese macaques (Macaca fuscata) that share their living space with American black bears harbouring $B$. transfuga. However, the involvement of this ascarid species was only confirmed by epidemiological observations (Sato et al. 2005).

Fertilized eggs of $B$. transfuga have a thick, mammillated, proteinaceous coat and an impermeable, desiccation-resistant lipid layer (Kazacos and Turek 1983; De Ambrogi et al. 2011). Similar to those of other Baylisascaris species, the eggs of $B$. transfuga become infective after approximately 2 weeks and can remain infective for at least 15 months under artificial conditions (Papini and Casarosa 1994). Eggs have been reported to persist under appropriate environmental conditions for up to 5 years (Sapp et al. 2017). Humans might be exposed to a risk of infection in a highly contaminated environment, such as that in animal enclosures in zoo parks and in nature (e.g. zoo staff, trappers and hunters) (De Ambrogi et al. 2011; Testini et al. 2011).

The aim of this study was to evaluate $B$. transfuga infection in bears living in Tatra National Park (the western part of the Carpathians) in southern Poland based on an examination of faecal samples using flotation and molecular identification. We assessed the efficiency of direct isolation of DNA from faecal samples using a commercial kit and a Chelex resinbased method of extracting genomic DNA from eggs isolated after flotation.

\section{Materials and methods}

In the present study, faecal material was collected from brown bears in Tatra National Park (the western part of the Carpathians) in southern Poland (Fig. 1). The protected area covers $212 \mathrm{~km}^{2}$ and, according to genetic monitoring (capture-mark-recapture population estimates), is inhabited by 36-52 bears (Zwijacz-Kozica et al. 2014). Because the National Park is visited each year by approximately three million tourists and is surrounded by dense settlements, the appearance of problem bears is a major concern.

\section{Faecal samples and flotation analysis}

Thirty-two faecal samples were collected from brown bears in Tatra National Park. Each faecal sample was recognized as having been deposited by a separate animal. Sampling was performed in 2014 (from March to November) and 2015 (from May to June). Until analysis by flotation and molecular examination were performed, the samples were maintained frozen at $-18{ }^{\circ} \mathrm{C}$. To recover $B$. transfuga eggs from bear faeces, flotation with a zinc sulphate $\left(\mathrm{ZnSO}_{4}\right)$-saturated solution (1.35 specific gravity) was performed (Euzeby 1981). For molecular analysis, the flotation was repeated for each positive sample, and $100 \mu$ of each supernatant with eggs was subjected to a Chelex resin-based DNA extraction (Walsh et al. 1991). Five faecal samples that were positive for B. transfuga eggs and five samples that were negative for eggs at the time of flotation analysis were used for molecular testing by PCR, with genomic DNA isolated directly from faecal samples using a commercial kit.

\section{Molecular procedures}

\section{Genomic DNA isolation}

Extraction of genomic DNA consisted of two parts:

a. Direct isolation of genomic DNA from faecal samples. In all, $200 \mathrm{mg}$ of each sample was weighed for DNA extraction using a soil DNA extraction kit (Eurx, Poland) according to the manufacturer's instructions.

b. Chelex resin-based DNA preparation (Walsh et al. 1991) from $B$. transfuga eggs recovered by flotation.

B. transfuga eggs were washed three times with MilliQ water to remove excess salts after the flotation procedure, and at each stage, centrifugation at $14000 \mathrm{rpm}$ was performed 
for $5 \mathrm{~min}$ to pellet the eggs prior to supernatant removal. Eggs were then re-suspended in $100 \mu$ l of MilliQ water. Twenty microlitres of the suspension was added to a $10 \%$ Chelex resin solution (1 g of Chelex® 100 Resin (Sigma) in $10 \mathrm{ml}$ of MilliQ water). Approximately $100 \mu \mathrm{l}$ of $0.5 \mathrm{~mm}$ diameter glass beads (Sartorius AG, Germany) were added to the sample, and the probes were pulverised for $10 \mathrm{~min}$ at $20 \mathrm{~Hz}$ in a TissueLyser II homogeniser (Qiagen, Germany) to mechanically disrupt the nematode eggs. After homogenization, $3 \mu \mathrm{l}$ of proteinase K (20 mg/ml, Sigma, USA) was added, and the sample was incubated at $55^{\circ} \mathrm{C}$ for $30 \mathrm{~min}$, followed by $5 \mathrm{~min}$ of incubation at $95^{\circ} \mathrm{C}$ to inactivate the enzyme. Finally, the sample was centrifuged at $14000 \mathrm{rpm}$ for $5 \mathrm{~min}$, and the supernatant was transferred into a new Eppendorf tube.

\section{PCR primers}

To amplify a 413-bp segment of cytochrome c oxidase 1 (COI), the COI-F and COI-R primers were used according to Sato et al. (2005).

\section{COI amplification by PCR}

PCR was carried out in $20 \mu \mathrm{l}$ volumes using OptiTaq polymerase (Eurx, Poland) and $2 \mu$ of DNA. The reaction conditions were as follows: initial denaturation at $94^{\circ} \mathrm{C}$ for $3 \mathrm{~min}$ followed by 35 cycles of denaturation at $94^{\circ} \mathrm{C}$ for $15 \mathrm{~s}$, annealing at $50^{\circ} \mathrm{C}$ for $15 \mathrm{~s}$ and elongation at $72^{\circ} \mathrm{C}$ for $1 \mathrm{~min}$. Final elongation was performed at $72{ }^{\circ} \mathrm{C}$ for $2 \mathrm{~min}$. The resulting PCR products were visualized on $1 \%$ agarose gels and purified using an exonuclease I/alkaline phosphatase mix (Thermo Scientific, USA). Positive samples were sequenced with PCR primers using BigDye Terminator v. 3.1 chemistry and an ABI3730xl genetic analyser at the DNA Sequencing Laboratory (Institute of Biochemistry and Biophysics, Polish Academy of Sciences). Sequencing reads were assembled into contigs using Seqman software (DNAStar, USA). The consensus nucleotide sequence of the COI fragment was aligned to the reference sequence obtained from the GenBank ${ }^{\mathrm{TM}}$ database (Johnson et al. 2008) using BLAST (Altschul et al. 1990).

\section{Results}

\section{Flotation analysis}

Based on the initial flotation analysis, the prevalence of ascarids in bears was $15.6 \%$. Among the 32 faecal samples that were analysed, five contained $31,97,105,116$ or 241 eggs per $1 \mathrm{~g}$ of faeces.

\section{PCR}

After confirmation of $B$. transfuga eggs in five samples by initial flotation analysis, DNA was directly isolated from each positive faecal sample using a commercial kit. All of these samples were found to be positive by using amplification with specific primers, that is., a 420-bp COI fragment was generated by PCR. The five samples that were negative for eggs in flotation analysis were tested in the same way, and one of them was identified as positive by the molecular assay.

Five supernatants with eggs from the positive samples recovered by flotation were subjected to a manual DNA isolation procedure using Chelex resin. PCR amplification was successful for all five of the tested samples. During the PCR amplification of COI, faeces with no eggs and a water sample were used as negative controls. The $B$. transfuga COI-specific PCR product from one positive sample isolated by Chelex resin was sequenced. The resulting sequence of the fragment was a $100 \%$ match to the $B$. transfuga mitochondrial COI sequence (accession number HQ671079) based on a BLAST comparison to the GenBank ${ }^{\mathrm{TM}}$ database. The nucleotide sequence was deposited in the GenBank ${ }^{\mathrm{TM}}$ database under the accession number KY973960.

\section{Discussion}

The current study reports molecular identification of B. transfuga in the small population of free-living brown bears in the protected area of Tatra Mountains National Park. Genomic DNA of the parasite was obtained from eggs retrieved from faecal samples after preliminary flotation by direct extraction from the same samples using a commercial kit. Extraction of DNA from ascarid eggs for PCR requires mechanical damage of their sheath (Dangoudoubiyam et al. 2009; De Ambrogi et al. 2011) or the use of enzymatic lysis (proteinase K) for an extended period of time. Lysis was previously used to obtain genomic DNA from soil samples contaminated with Toxocara spp. eggs (Borecka and Gawor 2008). De Ambrogi et al. (2011) successfully performed mechanical disruption of Baylisascaris transfuga eggs using a mixer mill with one stainless steel bead per sample, developing a method to extract DNA and run PCR directly from faecal samples. We directly detected the DNA of the parasite in bear faecal samples using a commercial kit, which was confirmed by amplifying the cox 1 gene fragment of the $B$. transfuga mitochondrial genome. PCR testing with directly extracted DNA was sensitive, as one positive sample was revealed among the five samples that were initially identified as negative during the initial flotation analysis.

A Chelex-based method (Walsh et al. 1991) was successfully adapted to prepare a PCR template from $B$. transfuga eggs. The samples were vortexed with $0.5 \mathrm{~mm}$ glass beads 
to mechanically disrupt the eggs in the presence of chelating Chelex resin, and proteinase $\mathrm{K}$ was then added for additional digestion of the egg coat. Chelex 100 resin is a chelating resin that enables ion exchange to bind transition metal ions. During the extraction process, the alkalinity of the solution and boiling break down cells and allow the chelating groups to bind to the cellular components, which protects DNA from degradation (Phillips et al. 2012). To our knowledge, Chelex resin has not been used previously to extract DNA from any ascaridoid nematodes.

Our attempts to perform Chelex resin extraction from regular faeces failed. The lack of a PCR amplification product was probably due to the residual PCR polymerase inhibitors that commonly exist in faeces.

Diagnosis of a $B$. transfuga infestation in bears commonly relies on the retrieval of eggs by conventional faecal flotation analysis (Finnegan 2009; De Ambrogi et al. 2011; Catalano et al. 2015; Bugmyrin et al. 2017). The eggs can be easily recognised; therefore, detection of the eggs by microscopy after flotation seems to be easy for the observer, except that the eggs of $B$. transfuga cannot be distinguished from those of other ascarids (Kazacos and Turek 1983). The sensitivity of faecal flotation techniques may be limited for $B$. transfuga, particularly due to its long prepatent period, negative results with even a high-intensity intestinal infection (Testini et al. 2011) and seasonal trends in the prevalence of $B$. transfuga in bears (Bugmyrin et al. 2017; Sapp et al. 2017). De Ambrogi et al. (2011) showed that the sensitivity of flotation for B. transfuga eggs was $60 \%$, with mixed results when flotation was repeated several times with the same samples. Unfortunately, the authors did not mention the number of eggs per gram that was retrieved by flotation from the collected faecal samples.

Different procedures have been used to test the capacity of a given method to detect DNA in Baylisascaris eggs, i.e. uninfected faecal samples are spiked with eggs and flotation is performed to retrieve the same eggs (Dangoudoubiyam et al. 2009) or samples spiked with the eggs are immediately subjected to extraction (De Ambrogi et al. 2011). In the present study, all five of the positive samples were positive according to the PCR assay with DNA isolated directly from faecal material. Moreover, one sample that scored negative in the preliminary flotation analysis was found to be positive in PCR analysis. De Ambrogi et al. (2011) demonstrated limited detection by PCR for $0.025 \mathrm{~g}$ aliquots of faecal matter spiked with two $B$. transfuga eggs, and no band was detected in PCR products from samples spiked with a single egg. These results show that a minimum of 80 eggs per gram of faeces is required to confirm infection by molecular examination. The present study shows that the sensitivity of molecular detection is related to the number of eggs recovered by flotation. Our results showing the high sensitivity of direct extraction of DNA from bear faecal samples combined with a PCR assay to obtain a 420-bp product with amplified COI fragments are in agreement with those of De Ambrogi et al. (2011).

This study presents the first screening of $B$. transfuga based on faecal sample examination with molecular identification via a PCR assay in the brown bear population in Tatra National Park in southern Poland. B. transfuga was first identified in a brown bear cub that was found dead in the Tatra Mountains in Poland; the cause of death was determined to be granulomatous peritonitis due to extraintestinal ascariasis via morphological identification at necropsy (Szczepaniak et al. 2012). In Europe, $B$. transfuga has been reported in free-living populations of brown bears in Slovakia (Finnegan 2009) and Croatia (De Ambrogi et al. 2011), with prevalence of 47 and $13.5 \%$, respectively, according to flotation results. A recent survey in the eastern part of the Scandinavian Peninsula (the Kola Peninsula, Russia) revealed Baylisascaris sp. eggs in $37.6 \%$ of brown bears (Bugmyrin et al. 2017). In the studies of Finnegan (2009) and Bugmyrin et al. (2017), the eggs detected in the samples were not identified by molecular assays and therefore probably belong to Baylisascaris transfuga. A study in Canada (Alberta and British Columbia) found the total prevalence of B. transfuga in the intestine of American black bears to be $60 \%$ (with $42.9 \%$ in cubs, $73.7 \%$ in juveniles and $50 \%$ in adults), while the prevalence was $53.8 \%$ in juvenile and adult grizzly bears (Catalano et al. 2015).

Infected bears can pass between 100 and 19,800 eggs per gram of faeces, and thus, environments can quickly become contaminated with large numbers of eggs. Baylisascaris eggs that are present in the environment or in captive animal facilities are difficult to eliminate or kill (Sapp et al. 2017). In Tatra National Park, food-conditioned brown bears approach tourist facilities inside the park and often enter neighbouring settlements; therefore, the possible risk to humans cannot be ignored. While there are no confirmed reports of larva migrans in humans following $B$. transfuga infection, experimental evidence with other Baylisascaris species shows that given a sufficiently high infection rate, larva migrans in people may be possible (Sapp et al. 2017).

In this study, faecal samples were collected from May to October. Due to the low number of secured samples, it was impossible to assess the seasonality of egg excretion. The prevalence of Baylisascaris eggs in faecal samples demonstrates a clear seasonal pattern, with peaks in summer (Bugmyrin et al. 2017). The large, three-year study of Finnegan (2009) in the Carpathian Mountains with 188 faecal secured samples showed seasonal changes in the prevalence of Baylisascaris sp. eggs in faeces: 9.5\% recorded in spring, $44.6 \%$ in summer and $70.8 \%$ in autumn. These data indicate that faecal sampling in fall allows one to obtain a more accurate picture of bear infection in a given area. However, some studies attempting to investigate seasonal trends of the 
prevalence of B. transfuga have shown conflicting results, with a higher prevalence in spring compared to fall or the opposite seasonal trend with peaks in fall (Sapp et al. 2017).

\section{Conclusions}

Diagnosis of $B$. transfuga in bears based on the examination of faecal samples requires molecular identification of genetic material isolated from excreted eggs. We show that direct extraction of $B$. transfuga DNA from bear faeces using a commercial kit is efficient for molecular assays. As an alternative, we present the effectiveness of a Chelex-based technique for extracting DNA from eggs. Although the proposed Chelex protocol has limitations related to the need to recover eggs from faecal samples, it allows easy and fast DNA isolation from the difficult-to-disrupt eggs of $B$. transfuga. Molecular tests including DNA of parasites extracted directly from faecal material have limits of detection related to the amount of eggs in the samples. Thus, using classical flotation to obtain eggs for PCR may increase the credibility of results, particularly in cases with a low number of excreted eggs. Microscopy remains the cornerstone for the diagnosis of many parasites, particularly for the detection of rare or emerging parasitic infections in humans and animals. The proposed Chelex protocol has a potential application in studies on intestinal parasites in wildlife in which conventional flotation is routinely used for microscopy.

Acknowledgements The authors would like to thank the staff of Tatra National Park for the collection of faecal samples.

\section{Compliance with ethical standards}

Conflict of interest The authors declare that they have no conflict of interest.

Open Access This article is distributed under the terms of the Creative Commons Attribution 4.0 International License (http:// creativecommons.org/licenses/by/4.0/), which permits unrestricted use, distribution, and reproduction in any medium, provided you give appropriate credit to the original author(s) and the source, provide a link to the Creative Commons license, and indicate if changes were made.

\section{References}

Aghazadeh M, Elson-Riggins J, Reljić S, De Ambrogi M, Huber D, Majnarić D, Hermosilla C (2015) Gastrointestinal parasites and the first report of Giardia spp. in a wild population of European brown bears (Ursus arctos) in Croatia. Veterinarski Arhiv 85:201-210

Altschul SF, Gish W, Miller W, Myers EW, Lipman DJ (1990) Basic local alignment search tool. J Mol Biol 215:403-410

Bauer C (2013) Baylisascariosis-infections of animals and humans with unusual' roundworms. Vet Parasitol 193:404-412
Borecka A, Gawor J (2008) Modification of gDNA extraction from soil for PCR designed for the routine examination of soil samples contaminated with Toxocara spp. eggs. J Helminthol 82:119-122

Bugmyrin SV, Tirronen KF, Panchenko DV, Kopatz A, Hagen SB, Eiken HG, Kuznetsova AS (2017) Helminths of brown bears (Ursus arctos) in the Kola Peninsula. Parasitol Res 116:1755-1760

Catalano S, Lejeune M, Tizzani P, Verocai GG, Schwantje H, Nelson C, Duignan PJ (2015) Helminths of grizzly bears (Ursus arctos) and American black bears (Ursus americanus) in Alberta and British Columbia, Canada. Can J Zool 93:765-772

Cho S, Egami M, Ohnuki H, Saito Y, Chinone S, Shichinohe K, Suganuma M, Akao N (2007) Migration behaviour and pathogenesis of five ascarid nematode species in the Mongolian gerbil Meriones unguiculatus. J Helminthol 81:43-47

Dangoudoubiyam S, Vemulapalli R, Kazakos KR (2009) PCR assays for detection of 283 Baylisascaris procyonis eggs and larvae. J Parasitol 95:571-577

De Ambrogi M, Aghazadeh M, Hermosilla C, Huber D, Majnaric D, Reljic S, Elson-Riggins J (2011) Occurrence of Baylisascaris transfuga in wild populations of European brown bears (Ursus arctos) as identified by a new PCR method. Vet Parasitol 179: 272-276

Duffy MS, Greaves TA, Burt MD (1994) Helminths of the black bear, Ursus americanus, in New Brunswick. J Parasitol 80:478-480

Euzeby J (1981) Diagnostic expérimental des helminthoses animales. Travaux pratiques d'helminthologie vétérinaire. Livre 2. Edition "Informations Techniques des Services Vétérinaires", Paris. p.31

Finnegan S (2009) Seasonal dynamics in the prevalence of Baylisascaris transfuga ova in the faeces of the brown bear (Ursus arctos) in Slovakia. Dissertation, University of Košice

Foster GW, Cunningham MW, Kinsella JM, Forrester DJ (2004) Parasitic helminths of black bear cubs (Ursus americanus) from Florida. J Parasitol 90:173-175

Johnson M, Zaretskaya I, Raytselis Y, Merezhuk Y, McGinnis S, Madden TL (2008) NCBI BLAST: a better web interface. Nucleic Acids Res 36:5-9

Kazacos KR, Turek JJ (1983) Scanning electron microscopy of the eggs of Baylisascaris procyonis, Baylisascaris transfuga and Parascaris equorum, and their comparison with Toxocara canis and Ascaris suum. Proc Helminthol Soc Wash 50:36-42

Moudgil AD, Singla LD, Singh MP (2014) First report on molecular identification and fenbendazole resistance against Baylisascaris transfuga infection in Melursus ursinus (sloth bear). Helminthologia 51:262-268

Papini R, Casarosa L (1994) Observations on the infectivity of Baylisascaris transfuga eggs for mice. Vet Parasitol 51:283-288

Papini R, Renzoni G, Lo Piccolo S, Casarosa L (1996) Ocular larva migrans and histopathological lesions in mice experimentally infected with Baylisascaris transfuga embryonated eggs. Vet Parasitol 61: 315-320

Phillips K, McCallum N, Welch L (2012) A comparison of methods for forensic DNA extraction: Chelex-1001 and the QIAGEN DNA investigator kit (manual and automated). Forensic Sci Int: Genetics 6: 282-285

Sapp SGH, Gupta P, Martin MK, Murray MH, Niedringhaus KD, Pfaff MA, Yabsley MJ (2017) Beyond the raccoon roundworm: the natural history of non-raccoon Baylisascaris species in the new world. Int J Parasitol Parasites Wildl 6:85-99

Sato H, Une Y, Kawakami S, Saito E, Kamiya H, Akao N, Furuoka H (2005) Fatal Baylisascaris larva migrans in a colony of Japanese macaques kept by a safari-style zoo in Japan. J Parasitol 91:716-719

Schaul JC (2006) Baylisascaris transfuga in captive and free-ranging populations of bears (family: Ursidae). Dissertation, Ohio State University

Sprent JFA (1968) Notes on Ascaris and Toxascaris with a definition of Baylisascaris gen. nov. Parasitology 58:185-198 
Szczepaniak K, Listos P, Łopuszyński W, Skrzypek T, Kazimierczak W (2012) Granulomatous peritonitis in a European brown bear caused by Baylisascaris transfuga. J Wildl Dis 48:517-519

Testini G, Papini R, Lia RP, Parisi A, Dantas-Torres F, Traversa D, Otranto D (2011) New insights into the morphology, molecular characterization and identification of Baylisascaris transfuga (Ascaridida, Ascarididae). Vet Parasitol 175:97-102
Walsh PS, Metzger DA, Higuchi R (1991) Chelex 100 as a medium for simple extraction of DNA for PCR-based typing from forensic material. BioTechniques 10:506-513

Zwijacz-Kozica T., Zięba F., Nowak Z., Majko P., Lenko P., Selva N. 2014. Getting transboundary cooperation into practice: Brown bear genetic monitoring in the Tatra mountains. $23^{\text {rd }}$ International Conference on Bear Research and Management, Thessaloniki, Greece, 05th-11th October 